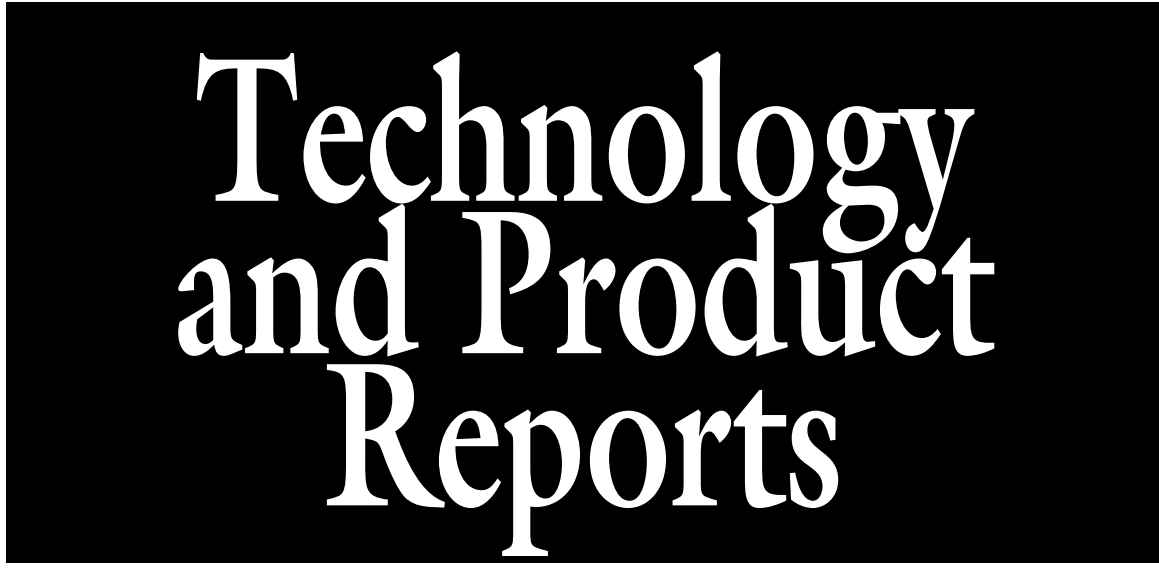

\section{Accuracy Varies for Commercially Available Soil Test Kits Analyzing Nitrate-Nitrogen, Phosphorus, Potassium, and pH}

\author{
Ben A. Faber ${ }^{1}$, A. James Downer ${ }^{1,3}$, Dirk Holstege ${ }^{2}$, \\ and Maren J. Mochizuki ${ }^{1}$
}

ADDITIONAL INDEX WORDS. soil nutrients, plant nutrition, fertilizer application, nitrate

SUMMARY. Soil testing is an important component of a plant nutrient management program for farmers, home gardeners, and agricultural service personnel. Results from five commercially available colorimetric soil test kits were compared with standard laboratory analyses for $\mathrm{pH}$, nitrate-nitrogen $\left(\mathrm{NO}_{3}\right)$, phosphorus $\left(\mathrm{P}_{2} \mathrm{O}_{5}\right)$, and potassium $\left(\mathrm{K}_{2} \mathrm{O}\right)$ content for Salinas clay loam soil with three cropping histories. The kits ranked in accuracy (frequency of match with analytical laboratory results) in the following sequence: La Motte Soil Test Kit, Rapitest, Quick Soiltest, Nitty-Gritty, and Soil Kit at $94 \%, 92 \%, 64 \%, 36 \%$, and $33 \%$. $\mathrm{NO}_{3}$ was most accurately determined by Rapitest and Quick Soiltest, $\mathrm{P}_{2} \mathrm{O}_{5}$ by Rapitest, and $\mathrm{pH}$ by La Motte Soil Test Kit. $\mathrm{K}_{2} \mathrm{O}$ was determined with equal accuracy by all but Soil Kit. The composition of the extractants may be an important factor affecting the accuracy of the test kit. For example, all kit extractants for $\mathrm{K}_{2} \mathrm{O}$ were composed of the same chemical and matched analytical laboratory results $82 \%$ of the time. By contrast, kits using an acid-based extractant for $\mathrm{NO}_{3}$ analysis more frequently matched the analytical laboratory results than kits using a zinc-based extractant $(P \leq 0.0001)$. La Motte Soil Test Kit had the largest range of $\mathrm{pH}$ measures, whereas Rapitest was relatively easy to use and interpret and is a practical choice for home gardeners or landscapers; both were more than $\mathbf{9 0 \%}$ accurate for this soil type. Although an important limitation of commercial test kits is the approximate or categorical value of nutrient content (i.e., low, medium, high), accurate test kits can yield results quickly and economically for improved nutrient management.

S oil testing is an important component of a plant nutrient management program and has been

Mention of a trademark, proprietary product, or vendor does not constitute a guarantee or warranty of the product by the Univ. of Calif. Coop. Ext. or the Univ. of Calif., Davis.

${ }^{1}$ University of California Cooperative Extension, Ventura County, 669 County Square Drive, Suite 100, Ventura, CA 93003

${ }^{2}$ University of California, Davis, Agriculture and Natural Resources Analytical Laboratory, 207 Hoagland Hall, Davis, CA 95616

${ }^{3}$ Corresponding author. E-mail: ajdowner@ucdavis.edu. standard practice for growers to aid in adjustment of fertilizer applications (Reisenauer, 1978). Soil testing is performed not only to improve plant growth, but also to reduce overapplication of fertilizers that may lead to nutrient toxicities, increased economic costs, and environmental pollution.

For maximum accuracy and benefit, soil testing must be conducted using reliable methods on correctly sampled soils [if the user is not trained in obtaining representative soil samples, test results, even from the same soil, can vary greatly (Voss, 1978)]. Test results must also be properly interpreted for a specific crop. Although interpretative guidelines are readily obtainable for many agronomic (Reisenauer, 1978) and horticultural crops and landscape trees (Bing et al., 1981), soil testing service is often available only through private laboratories in some states (in other states, the service is offered to private individuals by state cooperative extension offices). Cost for laboratory analysis for $\mathrm{NO}_{3}, \mathrm{P}_{2} \mathrm{O}_{5}$, and $\mathrm{K}_{2} \mathrm{O}$ was $\$ 20$ plus $\$ 10$ for $\mathrm{pH}$ per sample at the time of study (Agriculture and Natural Resources Analytical Laboratory, University of California, Davis) and results take $\approx 2$ weeks. A local private laboratory charged $\$ 20$ per nutrient or $\mathrm{pH}$ test or $\$ 68$ per sample for a comprehensive test that included $\mathrm{NO}_{3}$, $\mathrm{P}_{2} \mathrm{O}_{5}, \mathrm{~K}_{2} \mathrm{O}$, and $\mathrm{pH}$ (Fruit Growers Laboratory, unpublished data).

By contrast, many retail garden centers offer commercial test kits ranging in cost from $\$ 10$ to $\$ 50$ for multiple tests (the range of prices paid in this study) so that the cost per test can be relatively low. Home testing kits are also advantageous because results can be obtained within 1 to $2 \mathrm{~d}$. Commercial kits typically use a colorimetric method for indicating macronutrient and $\mathrm{pH}$ levels; soil is measured into a sample container, extractant is added, and after a specified time for the reaction, the user compares the color obtained with a color card corresponding to categorical nutrient and $\mathrm{pH}$ levels.

In this study, five commercially available test kits were compared with standard laboratory analysis of $\mathrm{NO}_{3}$,

\begin{tabular}{llll}
\hline $\begin{array}{l}\text { Units } \\
\begin{array}{l}\text { To convert U.S. to SI, } \\
\text { multiply by }\end{array}\end{array}$ & U.S. unit & SI unit & $\begin{array}{l}\text { To convert SI to U.S., } \\
\text { multiply by }\end{array}$ \\
\hline 29.5735 & $\mathrm{fl} \mathrm{oz}$ & $\mathrm{mL}$ & 0.0338 \\
25.4000 & inch $(\mathrm{es})$ & $\mathrm{mm}$ & 0.0394 \\
1 & $\mathrm{ppm}$ & $\mathrm{mg} \cdot \mathrm{kg}^{-1}$ & 1 \\
4.9289 & teaspoon $(\mathrm{s})$ & $\mathrm{cm}^{3}$ & 0.2029 \\
$\left({ }^{\circ} \mathrm{F} \div 1.8\right)+255.37$ & ${ }^{\circ} \mathrm{F}$ & $\mathrm{K}$ & $(\mathrm{K}-255.37) \times 1.8$
\end{tabular}


$\mathrm{P}_{2} \mathrm{O}_{5}, \mathrm{~K}_{2} \mathrm{O}$, and $\mathrm{pH}$ from the same soil type with three distinct cropping histories. The objectives were to identify differences in accuracy, if any, among test kits and to suggest a kit that most closely corresponds to analytical laboratory results.

\section{Materials and methods}

SoILs TESTED. A Salinas clay loam (fine-loamy, mixed, superactive, thermic Pachic Haploxerolls) was sampled near Santa Paula, Calif., in Sept. 2005 from three cropping areas containing impatiens (Impatiens holstii), cucumber (Cucumis satious), and petunia (Petunia $\times$ bybrida), herein referred to as soils 1,2 , and 3 , respectively. Cropping areas were fertilized according to current recommendations. Soil from each area was sampled in triplicate with a shovel, oven-dried, and passed through a 2 -mm sieve. Part of each sample was reserved for kit testing and the remainder was sent to an analytical laboratory. Standard laboratory procedures (Agriculture and Natural Resources Analytical Laboratory, University of California, Davis) were conducted for $\mathrm{NO}_{3}$ (Knepel, 2003), $\mathrm{P}_{2} \mathrm{O}_{5}$ (Olsen and Sommers, 1982), exchangeable $\mathrm{K}_{2} \mathrm{O}$ (Thomas, 1982), and $\mathrm{pH}$ (U.S. Salinity Laboratory Staff, 1954).

SoIL TEST KITs. Four of the kits, La Motte Soil Test Kit (La Motte Co., Chesteron, Md.), Rapitest (Luster Leaf Products, Woodstock, Ill.), Quick Soiltest (Hanna, Woonsocket, R.I.), and NittyGritty (La Motte Co., Chesteron, Md.) measured $\mathrm{NO}_{3}$, $\mathrm{P}_{2} \mathrm{O}_{5}, \mathrm{~K}_{2} \mathrm{O}$, and $\mathrm{pH}$. The Soil Kit (La Motte Co.) measured only $\mathrm{NO}_{3}$, $\mathrm{P}_{2} \mathrm{O}_{5}$, and $\mathrm{K}_{2} \mathrm{O}$. Kit results for macronutrients were categorical (high, medium, and low); $\mathrm{pH}$ results were numeric, rounding to half $\mathrm{pH}$ units for the Rapitest and one $\mathrm{pH}$ unit for the other three kits.

The manufacturers' instructions for each kit were followed for soil testing. Briefly, for the Quick Soiltest and the Rapitest, field soil was mixed with distilled water (1:5) for $1 \mathrm{~min}$ and was left to settle for $1 \mathrm{~d}$. For the Quick Soiltest, $2.5 \mathrm{~mL}$ of the supernatant extract was shaken for $30 \mathrm{~s}$ with respective reagents to test for $\mathrm{NO}_{3}$ and $\mathrm{P}_{2} \mathrm{O}_{5}$. For the $\mathrm{K}_{2} \mathrm{O}$ test, $0.5 \mathrm{~mL}$ of extract was shaken for $30 \mathrm{~s}$ with its respective reagent. The color of each solution was matched with its respective test card. For the $\mathrm{NO}_{3}$ test, the color was allowed to develop for $30 \mathrm{~s}$ before comparison. $\mathrm{pH}$ was measured by combining one-half teaspoon of soil, $3.0 \mathrm{~mL}$ of distilled water, and its reagent, shaking for $30 \mathrm{~s}$ and allowing color to develop for $5 \mathrm{~min}$ before comparing with its color card. For the Rapitest, the supernatant extract was added to the "test" and "reference" chambers of the respective proprietary testing box followed by its reagent in the testing chamber only. Color was allowed to develop for $10 \mathrm{~min}$ and compared with the semitransparent color chart attached to the front of the reference chamber for which the background was the reference supernatant. $\mathrm{pH}$ was measured by shaking one-half teaspoon of soil, the $\mathrm{pH}$ reagent, and distilled water and comparing it with the color chart after $1 \mathrm{~min}$.

The extraction method for NittyGritty and Soil Kit was similar with proprietary tablets composed of organic and inorganic salts dissolved in distilled water before the addition of field soil. Tests were conducted with the supernatant extract and the respective reagents; after 3 to $5 \mathrm{~min}$ of color development (depending on the test), the solutions were compared with their respective color cards. For $\mathrm{pH}$ (NittyGritty only), the reagent was dissolved in $10 \mathrm{~mL}$ of distilled water before adding one teaspoon of soil. After $30 \mathrm{~s}$ of shaking and $1 \mathrm{~min}$ of settling, the solution was compared with its color card.

The LaMotte Soil Test Kit used a separate extractant for each test. Generally, 1 to $2 \mathrm{~g}$ of soil (depending on the nutrient test) was added to the respective extractant, which was shaken and settled for 1 min each. The supernatant was added to a new test tube along with the respective nutrient indicator; this was mixed gently for $30 \mathrm{~s}$ after which color was allowed to develop for 5 min before comparing it with the chart. For $\mathrm{pH}, 1.5 \mathrm{~g}$ of soil was added to an indicator before allowing $10 \mathrm{~min}$ for color development and comparison.

Each soil was tested three times for each test and interpreted by two observers independently but simultaneously. For color interpretation, Rapitest recommends daylight, but not direct sunlight, to illuminate the solution, whereas La Motte Soil Test Kit and Quick Soiltest specify the light source to be located behind the user. The comparison card and the sample solutions were occasionally exposed to both $4100-\mathrm{K}$ clear metal halide fluorescent background lighting (the room contained 16 elements of $32 \mathrm{~W}$ each) and outdoor daylight and the color interpretation did not change. Therefore, to use a consistent, uniform light source that mimicked daylight, visual colorimetric comparisons for all tests were made with background $4100-\mathrm{K}$ metal halide fluorescent lighting.

COMPARING ANALYTICAL LABORATORY RESULTS WITH SOIL TEST KIT RESULTS. Analysis of variance was performed on the analytical laboratory results using the SAS GLM procedure (version 9.1; SAS Institute, Cary, N.C.) to verify the difference in nutrient content and $\mathrm{pH}$ of the soils tested. These numeric analytical laboratory results were converted to categories of low, medium, and high for comparison with the commercial test kit values (Table 1 ) based on the interpretative guide of Reisenauer (1978). The $\mathrm{pH}$ values from the analytical laboratory were rounded to the closest $\mathrm{pH}$ unit to compare with the test kit values.

$\chi^{2}$ analysis was conducted by hand to compare the frequency of correspondence between the soil kit and analytical laboratory results for $\mathrm{pH}$ and each nutrient. Each statistical test compared the number of successes (a match between soil kit and laboratory results) and the number of nonmatches with the expected frequencies of each. In some cases, the nature of the commercial kits suggested further $\chi^{2}$ tests based on the formulation of their extractants or the number of color choices on the

Table 1 . The association of the categorical rating scale of commercial soil test kits (low, medium, high) to the quantitative amount of macronutrients measured by an analytical laboratory (Reisenauer, 1978).

\begin{tabular}{lrrr}
\hline Analysis $^{\mathrm{z}}$ & Low & Medium & High \\
\hline $\mathrm{NO}_{3}-\mathrm{N}\left(\mathrm{mg} \cdot \mathrm{kg}^{-1}\right)^{y}$ & $<25$ & $25-60$ & $>60$ \\
$\mathrm{P}_{2} \mathrm{O}_{5}\left(\mathrm{mg} \cdot \mathrm{kg}^{-1}\right)$ & $<6$ & $6-10$ & $>10$ \\
$\mathrm{~K}_{2} \mathrm{O}\left(\mathrm{mg} \cdot \mathrm{kg}^{-1}\right)$ & $<50$ & $50-80$ & $>80$ \\
\hline
\end{tabular}

${ }^{2} \mathrm{NO}_{3}-\mathrm{N}, \mathrm{P}_{2} \mathrm{O}_{5}$, and $\mathrm{K}_{2} \mathrm{O}$ are nitrate-nitrogen, Olsenphosphorus, and exchangeable potassium, respectively.

${ }^{\mathrm{y}} \mathrm{lmg} \cdot \mathrm{kg}^{-1}=1 \mathrm{ppm}$ 
interpretative cards. According to the commercial kits, the soils were generally similar; frequencies for all soils were therefore pooled for these statistical tests $\mathrm{NO}_{3}$ for soil 2 was the exception but yielded similar statistical results when analyzed on its own compared with being pooled with the other soils; the results for $\mathrm{NO}_{3}$ are therefore still presented as pooled soils). $\chi^{2}$ tests also determined whether the differences in correspondence for a single commercial kit among the three soil types were the result of chance.

\section{Results and discussion}

The nutrient content and $\mathrm{pH}$ at the three soil locations were statistically distinct $(P \leq 0.001$; Table 2$)$ based on the laboratory analysis, except the $\mathrm{P}_{2} \mathrm{O}_{5}$ content of soil 3 , which was similar to soils 1 and 2 (Table 2). Once categorical values were assigned to the analytical laboratory results and $\mathrm{pH}$ was rounded to the nearest whole number for comparison with soil test kits results, however, the three soils were very similar (Table $2)$. Generally, the soils rated high (Table 1) for all nutrients, which probably resulted from prior cropping. Soil 2 had low to medium levels of $\mathrm{NO}_{3}$ (Tables 1 and 2), probably because the nitrogen demands of cucumber were high after 3 months of growth. Additionally, $\mathrm{NO}_{3}$ is the most active pool of soil nitrogen and changes constantly and relatively quickly; the static result may not accurately represent the soil $\mathrm{NO}_{3}$ content.

$\mathrm{pH}$ results from LaMotte Soil Test Kit and Rapitest generally matched laboratory results, although Rapitest measured $\mathrm{pH} 6.5$ for all tests regardless of the soil (Table 3 ). Soils 1 and 3 proved to be in the $\mathrm{pH} 6.5$ range, but the $\mathrm{pH}$ of soil 2 was 7.8 , technically beyond the capacity of Rapitest $(\mathrm{pH}$ 4.5 to 7.5 ). NittyGritty did not match laboratory results at all; the correspondence of Quick Soiltest results was intermediate (Table 3 ). Thus, the frequency of matching analytical laboratory results for $\mathrm{pH}$ depended on the soil kit used for all soils $(P \leq 0.05$; Table 4$)$. The kits generally indicated lower $\mathrm{pH}$ values than the analytical laboratory.

Results from LaMotte Soil Test Kit, Rapitest, and Quick Soiltest generally matched the analytical laboratory results for $\mathrm{NO}_{3}$ and $\mathrm{P}_{2} \mathrm{O}_{5}$,

Table 2. Macronutrient content and $\mathrm{pH}$ of Salinas clay loam with three crops measured by the Agriculture and Natural Resources Analytical Laboratory, University of California, Davis ${ }^{\mathrm{z}}$.

\begin{tabular}{|c|c|c|c|c|c|c|}
\hline \multirow[b]{2}{*}{ Analysis $^{\mathrm{y}}$} & \multicolumn{2}{|c|}{ Soil 1: Impatiens } & \multicolumn{2}{|c|}{ Soil 2: Cucumber } & \multicolumn{2}{|c|}{ Soil 3: Petunia } \\
\hline & Mean \pm SE & $\mathbf{C V}$ & Mean \pm SE & $\mathrm{CV}$ & Mean \pm SE & $\mathrm{CV}$ \\
\hline $\mathrm{pH}$ & $6.9 \pm 0$ & 7 & $7.8 \pm 0$ & 8 & $7.2 \pm 0$ & 7 \\
\hline $\mathrm{NO}_{3}-\mathrm{N}\left(\mathrm{mg} \cdot \mathrm{kg}^{-1}\right)^{\mathrm{x}}$ & $365 \pm 9$ & $\mathrm{H}^{\mathrm{w}}$ & $24 \pm 2$ & L-M & $188 \pm 19$ & $\mathrm{H}$ \\
\hline $\mathrm{P}_{2} \mathrm{O}_{5}\left(\mathrm{mg} \cdot \mathrm{kg}^{-1}\right)$ & $103 \pm 2$ & $\mathrm{H}$ & $83 \pm 5$ & $\mathrm{H}$ & $94 \pm 1$ & $\mathrm{H}$ \\
\hline $\mathrm{K}_{2} \mathrm{O}\left(\mathrm{mg} \cdot \mathrm{kg}^{-1}\right)$ & $1310 \pm 11$ & $\mathrm{H}$ & $632 \pm 16$ & $\mathrm{H}$ & $1080 \pm 30$ & $\mathrm{H}$ \\
\hline
\end{tabular}

${ }^{\mathrm{z}}$ Mean values of three samples. The categorical value $(\mathrm{CV})$ was assigned for comparison with commercial test kit values ( $\mathrm{pH}$ was rounded to the nearest whole number)

${ }^{y} \mathrm{NO}_{3}-\mathrm{N}, \mathrm{P}_{2} \mathrm{O}_{5}$, and $\mathrm{K}_{2} \mathrm{O}$ are nitrate-nitrogen, Olsen-extractable phosphorus, and exchangeable potassium, respectively

${ }^{\mathrm{x}} \mathrm{l} \mathrm{mg} \cdot \mathrm{kg}^{-1}=1 \mathrm{ppm}$.

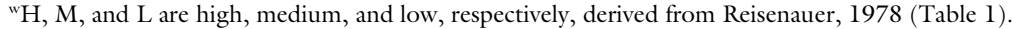

$\mathrm{SE}=$ standard error

Table 3. Commercial soil test kit results for Salinas clay loam soil with three crops.

\begin{tabular}{|c|c|c|c|c|c|c|c|}
\hline \multirow[b]{2}{*}{$\underline{\mathbf{K i t}^{\mathrm{z}}}$} & \multirow[b]{2}{*}{ Analysis $^{\mathrm{y}}$} & \multicolumn{2}{|c|}{$\begin{array}{c}\text { Soil 1: } \\
\text { Impatiens }\end{array}$} & \multicolumn{2}{|c|}{$\begin{array}{c}\text { Soil 2: } \\
\text { Cucumber }\end{array}$} & \multicolumn{2}{|l|}{$\begin{array}{l}\text { Soil 3: } \\
\text { Petunia }\end{array}$} \\
\hline & & Kit results ${ }^{x}$ & $\mathrm{~F}_{\mathrm{m}}{ }^{\mathrm{w}}$ & Kit results & $\overline{F_{m}}$ & Kit results & $\mathrm{F}_{\mathrm{m}}$ \\
\hline \multirow[t]{4}{*}{ Rapitest } & $\mathrm{pH}$ & $6.5,6.5,6.5$ & 3 & $6.5,6.5,6.5$ & 0 & $6.5,6.5,6.5$ & 3 \\
\hline & $\mathrm{NO}_{3}$ & $\mathrm{H}, \mathrm{H}, \mathrm{H}$ & 3 & $\mathrm{M}, \mathrm{M}, \mathrm{M}$ & 3 & $\mathrm{H}, \mathrm{H}, \mathrm{H}$ & 3 \\
\hline & $\mathrm{P}_{2} \mathrm{O}_{5}$ & $\mathrm{H}, \mathrm{H}, \mathrm{H}$ & 3 & $\mathrm{H}, \mathrm{H}, \mathrm{H}$ & 3 & $\mathrm{H}, \mathrm{H}, \mathrm{H}$ & 3 \\
\hline & $\mathrm{K}_{2} \mathrm{O}$ & $\mathrm{H}, \mathrm{H}, \mathrm{H}$ & 3 & $\mathrm{H}, \mathrm{H}, \mathrm{H}$ & 3 & $\mathrm{H}, \mathrm{H}, \mathrm{H}$ & 3 \\
\hline \multirow[t]{4}{*}{ Quick Soiltest } & $\mathrm{pH}$ & $5.0,5.0,7.0$ & 1 & $6.5,6.5^{\mathrm{v}, \mathrm{u}}$ & 0 & $6.5,6.5^{v, u}$ & 2 \\
\hline & $\mathrm{NO}_{3}$ & $\mathrm{H}, \mathrm{H}, \mathrm{L}$ & 2 & $\mathrm{~L}, \mathrm{~L}, \mathrm{~L}$ & 3 & $\mathrm{H}, \mathrm{H}, \mathrm{L}$ & 2 \\
\hline & $\mathrm{P}_{2} \mathrm{O}_{5}$ & $\mathrm{H}, \mathrm{H}, \mathrm{H}$ & 3 & $\mathrm{H}, \mathrm{H}, \mathrm{H}^{\mathrm{v}}$ & 3 & $\mathrm{H}, \mathrm{H}, \mathrm{H}$ & 3 \\
\hline & $\mathrm{K}_{2} \mathrm{O}$ & $\mathrm{H}, \mathrm{L}, \mathrm{L}$ & 1 & $\mathrm{M}, \mathrm{M}, \mathrm{M}$ & 0 & $\mathrm{H}, \mathrm{H}, \mathrm{H}$ & 3 \\
\hline \multicolumn{8}{|l|}{ La Motte } \\
\hline \multirow[t]{4}{*}{ Soil Test Kit } & $\mathrm{pH}$ & $7.0,7.0,7.0$ & 3 & $8.0,8.0,8.0$ & 3 & $6.5,7,7$ & 3 \\
\hline & $\mathrm{NO}_{3}$ & $\mathrm{H}, \mathrm{H}, \mathrm{H}$ & 3 & $\mathrm{~L}, \mathrm{~L}, \mathrm{~L}$ & 3 & $\mathrm{H}, \mathrm{H}, \mathrm{H}$ & 3 \\
\hline & $\mathrm{P}_{2} \mathrm{O}_{5}$ & $\mathrm{H}, \mathrm{M}, \mathrm{L}$ & 1 & $\mathrm{H}, \mathrm{H}, \mathrm{H}$ & 3 & $\mathrm{H}, \mathrm{H}, \mathrm{H}$ & 3 \\
\hline & $\mathrm{K}_{2} \mathrm{O}$ & $\mathrm{H}, \mathrm{H}, \mathrm{H}$ & 3 & $\mathrm{H}, \mathrm{H}, \mathrm{H}$ & 3 & $\mathrm{H}, \mathrm{H}, \mathrm{H}$ & 3 \\
\hline \multirow[t]{3}{*}{ Soil Kit ${ }^{t}$} & $\mathrm{NO}_{3}$ & $\mathrm{~L}, \mathrm{~L}, \mathrm{~L}$ & 0 & $\mathrm{~L}, \mathrm{~L}, \mathrm{~L}$ & 3 & $\mathrm{M}, \mathrm{M}, \mathrm{L}$ & 0 \\
\hline & $\mathrm{P}_{2} \mathrm{O}_{5}$ & $\mathrm{M}, \mathrm{M}, \mathrm{M}$ & 0 & $\mathrm{M}, \mathrm{M}, \mathrm{M}^{\mathrm{v}}$ & 0 & $\mathrm{M}, \mathrm{M}, \mathrm{M}$ & 0 \\
\hline & $\mathrm{K}_{2} \mathrm{O}$ & $\mathrm{M}, \mathrm{M}, \mathrm{M}$ & 0 & $\mathrm{H}, \mathrm{H}, \mathrm{H}$ & 3 & $\mathrm{H}, \mathrm{H}, \mathrm{H}$ & 3 \\
\hline \multirow[t]{4}{*}{ NittyGritty } & $\mathrm{pH}$ & $5.0,6.0,6.0$ & 0 & $5.0,6.0,6.0$ & 0 & $5.0,6.0,6.0$ & 0 \\
\hline & $\mathrm{NO}_{3}$ & $\mathrm{M}, \mathrm{L}, \mathrm{M}$ & 0 & $\mathrm{~L}, \mathrm{~L}, \mathrm{~L}$ & 3 & $\mathrm{H}, \mathrm{M}, \mathrm{L}$ & 1 \\
\hline & $\mathrm{P}_{2} \mathrm{O}_{5}$ & $\mathrm{M}, \mathrm{M}, \mathrm{M}$ & 0 & $\mathrm{M}, \mathrm{M}, \mathrm{M}$ & 0 & $\mathrm{M}, \mathrm{M}, \mathrm{M}$ & 0 \\
\hline & $\mathrm{K}_{2} \mathrm{O}$ & $\mathrm{H}, \mathrm{H}, \mathrm{H}$ & 3 & $\mathrm{H}, \mathrm{H}, \mathrm{H}$ & 3 & $\mathrm{H}, \mathrm{H}, \mathrm{H}$ & 3 \\
\hline
\end{tabular}

${ }^{\mathrm{z}}$ Rapitest (Luster Leaf Products, Woodstock, Ill.), Quick Soiltest (Hanna, Woonsocket, R.I.), La Motte Soil Test Kit, Soil Kit, and NittyGritty (La Motte Co., Chesteron, Md.).

${ }^{y} \mathrm{NO}_{3}-\mathrm{N}, \mathrm{P}_{2} \mathrm{O}_{5}$, and $\mathrm{K}_{2} \mathrm{O}$ are nitrate-nitrogen, phosphorus, and potassium, respectively.

${ }^{x} \mathrm{H}, \mathrm{M}$, and $\mathrm{L}$ are high, medium, and low, respectively, derived from Reisenauer, 1978 (Table 1 ).

wThree tests for each soil and nutrient/pH were conducted. The frequency that the soil test kits results matched analytical laboratory results $\left(\mathrm{F}_{\mathrm{m}}\right)$, ranging from 0 (no test soil kit results matched laboratory results) to 3 (all soil kit results matched laboratory results), is presented in a separate column.

${ }^{\mathrm{V}}$ Occasionally a test yielded no interpretable result.

"Observers independently interpreted results differently in at least two of the three tests; the higher categorical value was used.

${ }^{t}$ Soil Kit did not test $\mathrm{pH}$.

whereas Soil Kit and NittyGritty did not (Table 3). The frequency of correspondence between the laboratory and commercial test kits depended on the kit used in most cases $(P \leq 0.05$; Table 4). Test kits did not account for differences in correspondence for $\mathrm{NO}_{3}$ in soil $3(P \geq 0.05$; Table 4$)$, probably because NittyGritty and Soil Kit had few matches with analytical laboratory readings (Table $3)$. The frequency of matching may have depended on the use of an acidbased extractant for $\mathrm{NO}_{3}$ (LaMotte Soil Test Kit, Rapitest, and Quick Soiltest) rather than a zinc-based one (Soil Kit and NittyGritty) $(P \leq$ 0.0001 ; Table 5 ). There was no statistical difference in frequency of matching among kits using an 
Table 4. Probability values and test statistics (TS) for $\chi^{2}$ analysis derived from the observed frequency of matching between commercial test kits [Rapitest (Luster Leaf Products, Woodstock, Ill.), Quick Soiltest (Hanna, Woonsocket, R.I.), La Motte Soil Test Kit, Soil Kit, and NittyGritty (La Motte Co., Chesteron, Md.)] and analytical laboratory results compared with the expected frequency of a match on Salinas clay loam soil with three crops.

\begin{tabular}{|c|c|c|c|c|c|c|}
\hline \multirow[b]{2}{*}{ Analysis $^{z}$} & \multicolumn{2}{|c|}{$\begin{array}{c}\text { Soil 1: } \\
\text { Impatiens }\end{array}$} & \multicolumn{2}{|c|}{$\begin{array}{c}\text { Soil 2: } \\
\text { Cucumber }\end{array}$} & \multicolumn{2}{|c|}{$\begin{array}{l}\text { Soil 3: } \\
\text { Petunia }\end{array}$} \\
\hline & $P \leq$ & $\mathrm{TS}^{\mathrm{y}}$ & $P \leq$ & $\overline{T S}$ & $P \leq$ & TS \\
\hline $\mathrm{pH}$ & 0.05 & 9 & 0.01 & 12 & 0.05 & 10 \\
\hline $\mathrm{NO}_{3}$ & 0.0001 & 17 & 0.0001 & 17 & NS & 9 \\
\hline $\mathrm{P}_{2} \mathrm{O}_{5}$ & 0.001 & 12 & 0.0001 & 15 & $0.0001,0.0001^{\mathrm{x}}$ & 24,18 \\
\hline $\mathrm{K}_{2} \mathrm{O}$ & 0.001 & 12 & 0.0001 & 15 & $\mathrm{~N} / \mathrm{A}^{\mathrm{w}}$ & \\
\hline
\end{tabular}

${ }^{2} \mathrm{NO}_{3}-\mathrm{N}, \mathrm{P}_{2} \mathrm{O}_{5}$, and $\mathrm{K}_{2} \mathrm{O}$ are nitrate-nitrogen, phosphorus, and potassium, respectively.

y Test statistics are included for each test to illustrate how each $P$-value was derived. The $\mathrm{df}$ for each test $=4$, except for $\mathrm{pH}$ tests $=3$.

${ }^{x} \mathrm{P}_{2} \mathrm{O}_{5}$ content in soil 3 was found to be equal to soil $\mathrm{l}$ and 2 ; results are pooled tests of soils $\mathrm{l}$ and 3 and soils 2 and 3 , respectively.

"N/A, not applicable for soil 3, 100\% of the commercial kit results matched those of the analytical laboratory for $\mathrm{K}_{2} \mathrm{O}$.

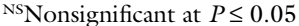

Table 5. Probability values, test statistics (TS) and df for $\chi^{2}$ analysis derived from the observed frequency of matching between commercial test kits [Rapitest (Luster Leaf Products, Woodstock, Ill.), Quick Soiltest (Hanna, Woonsocket, R.I.), La Motte Soil Test Kit, Soil Kit, and NittyGritty (La Motte Co., Chesteron, Md.)] and analytical laboratory results for Salinas clay loam soil.

\begin{tabular}{|c|c|c|c|}
\hline Analysis $^{z}$ & $P \geq$ & TS $^{\mathbf{y}}$ & df \\
\hline $\mathrm{pH}$ (four commercial kits) ${ }^{\mathrm{x}}$ & 0.0001 & 20 & 4 \\
\hline $\mathrm{NO}_{3}$ (all commercial kits) & 0.0001 & 27 & 4 \\
\hline Kits using acid-based extraction ${ }^{\mathrm{w}}$ versus zinc-based ${ }^{\mathrm{v}}$ & 0.0001 & 27 & $1^{\mathrm{u}}$ \\
\hline Kits with four or more colorimetric chart choices ${ }^{\mathrm{w}}$ versus three $^{\mathrm{v}}$ & 0.0001 & 27 & $1^{\mathrm{u}}$ \\
\hline Acid-based kits onlyw & NS & 6 & 2 \\
\hline $\mathrm{P}_{2} \mathrm{O}_{5}$ (all commercial kits) & 0.0001 & 29 & 4 \\
\hline Kits without isoascorbic acid extractant ${ }^{\mathrm{w}}$ versus with ${ }^{\mathrm{v}}$ & 0.0001 & 24 & $1^{\mathrm{u}}$ \\
\hline Kits with four or more colorimetric chart choices ${ }^{\mathrm{w}}$ versus three $^{\mathrm{v}}$ & 0.0001 & 24 & $1^{\mathrm{u}}$ \\
\hline Kits without isoascorbic acid only ${ }^{\mathrm{w}}$ & NS & 4 & 2 \\
\hline $\mathrm{K}_{2} \mathrm{O}$ (all commercial kits) & 0.01 & 11 & 4 \\
\hline \multicolumn{4}{|l|}{ Kits with three or more extractant components ${ }^{\mathrm{w}}$ versus } \\
\hline two or less ${ }^{v}$ & NS & 2 & 1 \\
\hline
\end{tabular}

${ }^{2} \mathrm{NO}_{3}-\mathrm{N}, \mathrm{P}_{2} \mathrm{O}_{5}$, and $\mathrm{K}_{2} \mathrm{O}$ are nitrate-nitrogen, phosphorus, and potassium, respectively.

'Test statistics are included for each test to illustrate how each $P$ value was derived. In some cases, single df $\chi^{2}$ tests were suggested by the formulation of the respective extractants of the commercial kits.

xRapitest, Quick Soiltest, La Motte Soil Test Kit, and NittyGritty.

"Rapitest, Quick Soiltest, and La Motte Soil Test Kit.

NittyGritty and Soil Kit.

"These comparisons grouped the same test kits and therefore resulted in the same $P$ value and TS.

acid-based extractant for $\mathrm{NO}_{3}(P \geq$ 0.10 ; Table 5$)$, indicating that regardless of the acid type, these extractants were equally effective.

For $\mathrm{P}_{2} \mathrm{O}_{5}$, the commercial kits with results that least matched the analytical laboratory used extractants with isoascorbic acid (Soil Kit and NittyGritty) $(P \leq 0.0001$; Tables 3 and 5 ). This ingredient may have reduced the $\mathrm{P}_{2} \mathrm{O}_{5}$ extractant potential compared with the other ingredients found in kits with a higher frequency of matches. For example, the $\mathrm{P}_{2} \mathrm{O}_{5}$ extractants for LaMotte Soil Test Kit, Rapitest, and Quick Soiltest were composed of multiple ingredients but did not contain isoascorbic acid; there was no difference in the frequency of matching among these three kits $(P \geq 0.10$; Table 5).

Although these differences may be related to the methods of extraction rather than the composition of the extractants, Soil Kit, NittyGritty, and LaMotte Soil Test Kit had similar extraction methods with the La Motte Soil test kit yielding results most frequently matching analytical laboratory testing. Another factor affecting correspondence (i.e., matching) to laboratory results may be the result of the degree of color gradation on the colorimetric cards used for interpreting results. The tests with minimal correspondence had only three color choices for $\mathrm{NO}_{3}$ and $\mathrm{P}_{2} \mathrm{O}_{5}$ content (whereas the others had four or more $(P \leq 0.0001$; Table 5$)$. This level of precision may also relate to the use of more effective extractants for LaMotte Soil Test Kit, Rapitest, and Quick Soiltest.

Soil Kit and NittyGritty analyzed $\mathrm{K}_{2} \mathrm{O}$ content with greater accuracy than for the other nutrients; the commercial tests in total corresponded with the analytical laboratory $82 \%$ of the time for this test. For soil 3, $100 \%$ of the commercial test results matched those of the analytical laboratory results (Table 3 ). For soils 1 and 2, Quick Soiltest and Soil Kit varied, whereas the other tests consistently matched the analytical laboratory (Table 3 ). In fact, the differences in correspondence for Quick Soiltest among all three soils was the result of chance (test statistic $=6$ with $2 \mathrm{df}$, $P \geq 0.05)$. Furthermore, there was no difference between test extractants using multiple ingredients compared with two ingredients $(P \geq 0.10$; Table 5 ) probably because all were based on sodium tetraphenyl boron or sodium tetraphenyl borate; this uniformity in extractant composition, in contrast to the variety of ingredients used in tests for other nutrients, probably resulted in better correspondence among the test kits and with the analytical laboratory results.

Precautionary measures for these commercial kits may increase their accuracy. For Soil Kit and NittyGritty, the extracting powders that came with the kits dissolved poorly; these kits generally yielded inaccurate results, but pulverizing the tablets or powders may increase extraction potential. Interpretation of color development should be made only within the time specified by the kit instructions because color intensity could vary within minutes. The source of light could potentially influence color interpretation, which is briefly mentioned in the instructions for Rapitest, La Motte Soil Test Kit, and Quick Soiltest, but not for Soil Kit and NittyGritty. In this investigation, the comparison card and the sample solution varied similarly when exposed to $4100-\mathrm{K}$ clear metal halide fluorescent lighting and occasionally to outdoor daylight; the color interpretation did not change. However, 
when the solutions were occasionally compared with 6200-K "daylight" fluorescent backlight, the color of both the solution and card was different from the color under $4100-\mathrm{K}$ fluorescent lighting and natural daylight. These differences stress the importance of using a uniform light source when interpreting reaction color. Interpretation can occasionally vary depending on the user. In this study, the observers independently interpreted the same result for $91 \%$ of the tests; this would probably be an acceptable proportion for a home gardener or farmer individually conducting tests, but occasional independent interpretation by another source may change the result. Finally, these results were obtained using one soil type; variation in accuracy may occur when testing other soils.

La Motte Soil Test Kit results corresponded to those from the analytical laboratory for $\mathrm{pH}$ and all nutrients ( $94 \%$ of the tests matched). This kit is suitable for growers, cooperative extension personnel, and university-level laboratory classes because it proved to be accurate over a wide $\mathrm{pH}$ range. The individual extractants and indicators for each test, although accurate, may be cumbersome for the home gardener, however. Rapitest yielded accurate results 92\% of the time for all nutrients and $\mathrm{pH}$ less than 7.5 and was comparatively easy to use and interpret with colorcoded extractants and test boxes and instructions in large print on stiff paperboard; this kit would be a good choice for the home gardener. Quick Soiltest matched the analytical laboratory results $64 \%$ of the time because $\mathrm{K}_{2} \mathrm{O}$ and $\mathrm{pH}$ results did not match those obtained from the laboratory analysis. Soil Kit and NittyGritty were unable to reproduce laboratory analysis findings for $\mathrm{P}_{2} \mathrm{O}_{5}$ in any soil. Because some kits underestimate nutrient concentrations, overapplications of fertilizer could result from their use.

An important limitation of all commercial test kits is the approximate or categorical value of nutrient levels into broad categories of low, medium, or high. Analytical laboratories must be used when precise nutrient levels or interpretation are required. Nevertheless, commercially available kits such as Rapitest and La Motte Soil Test Kit were $92 \%$ and $94 \%$ accurate, respectively, for the soils tested and are a fast and economic means by which farmers, home gardeners, and agricultural service personnel can improve nutrient management for crop production and environmental protection.

\section{Literature cited}

Bing, A., J.W. Boodley, C.F. Gorzig, J. Gruttadaurio, R.W. Langhans, J.G.
Seeley, R.K. Horst, M.L. Daughtrey, D.B. Zepp, M. Semel, and L.D. Albright. 1981. Cornell recommendations for commercial floriculture crops, cultural practices and production programs. Cornell University, Ithaca, N.Y.

Knepel, K. 2003. Determination of nitrate in $2 \mathrm{M} \mathrm{KCl}$ soil extracts by flow injection analysis. QuikChem Method 12-107-04-1-B. Lachat Instruments, Loveland, Colo.

Olsen, S.R. and L.E. Sommers. 1982. Phosphorus, p. 403-430. In: A.L. Page (ed.). Methods of soil analysis: Part 2. Chemical and microbiological properties. Amer. Soc. Agron. Monogr. 9.

Reisenauer, H.M. (ed.). 1978. Soil and plant tissue-testing in California. Div. Agr. Sci., Univ. Calif. Bul. 1879.

Thomas, G.W. 1982. Exchangeable cations, p. 159-165. In: A.L. Page (ed.). Methods of soil analysis: Part 2. Chemical and microbiological properties. Amer. Soc. Agron. Monogr. 9.

U.S. Salinity Laboratory Staff. 1954. pH reading of saturated soil paste, p. 102. In: L.A. Richards (ed.). Diagnosis and improvement of saline and alkali soils. Hdbk. 60, U.S. Dept. Agr., Washington, D.C.

Voss, R.E. 1978. Uses and limitations of soil testing, p. 35. In: H.M. Reisenauer (ed.). Soil and plant tissue-testing in California, Div. Agr. Sci., Univ. of Calif., Bul. 1879. 